\title{
The Effect of Phragmites australis Dieback on Channel Sedimentation in the Mississippi River Delta: A Conceptual Modeling Study
}

\author{
Kelin Hu ${ }^{1, *}$, Ehab Meselhe ${ }^{1}$ and J. Andrew Nyman ${ }^{2}$ \\ 1 Department of River-Coastal Science and Engineering, School of Science and Engineering, Tulane University, \\ New Orleans, LA 70118, USA; emeselhe@tulane.edu \\ 2 School of Renewable Natural Resources, Louisiana State University Agricultural Center, \\ Baton Rouge, LA 70803, USA; jnyman@1su.edu \\ * Correspondence: khu1@tulane.edu
}

Citation: $\mathrm{Hu}, \mathrm{K}$.; Meselhe, E.;

Nyman, J.A. The Effect of Phragmites australis Dieback on Channel

Sedimentation in the Mississippi River Delta: A Conceptual Modeling Study. Water 2021, 13, 1407. https:// doi.org/10.3390/w13101407

Academic Editors: John W. Day and G. Paul Kemp

Received: 31 March 2021

Accepted: 14 May 2021

Published: 18 May 2021

Publisher's Note: MDPI stays neutral with regard to jurisdictional claims in published maps and institutional affiliations.

Copyright: () 2021 by the authors. Licensee MDPI, Basel, Switzerland. This article is an open access article distributed under the terms and conditions of the Creative Commons Attribution (CC BY) license (https:// creativecommons.org/licenses/by/ $4.0 /)$.

\begin{abstract}
Phragmites australis is a globally distributed wetland plant. At the mouth of the Mississippi River, P. australis on natural levees of the network of distributary channels appears to increase the flow in the deep draft navigation channel, which, in turn, may reduce the sedimentation and benefit the navigation dredging. For several years, P. australis has been dying in the Mississippi River's Bird's Foot Delta, which appears to be shortening the distributary channels and increasing the lateral flow from the remaining portions. A conceptual model based on D-FLOW FM was applied to calculate channel sedimentation in a series of idealized deltaic systems to predict the consequences of $P$. australis dieback and other factors that diminish the delta complexity, such as sea-level rise and subsidence, on sedimentation in the distributary channels. Channel complexity in each system, which was quantified with an index ranging from 0 to 10 that we developed. Model results indicate that sedimentation was insensitive to the channel complexity in simple deltas but was sensitive to the channel complexity in complex deltas, such as the current Mississippi River Delta with extensive $P$. australis. Channel sedimentation remains stable from 0 until the channel complexity index reaches 6. In more complex deltas, the sedimentation decreases rapidly as the channel complexity increases. The sedimentation is also affected by waves, river discharge, sediment concentration, grain sizes, and bed level. River managers in Louisiana may benefit from new models based on bathymetric data throughout the Bird's Foot Delta; data on the effects of the P. australis belowground biomass on bank erodibility across a range of current velocities; and data on the effects of P. australis stem density, diameter, and height on the lateral flow across a range of river stages and tidal stages to help them decide how much to respond to Phragmites dieback. Options include increased navigation dredging, increased restoration of the channel complexity via a thin layer of sediment deposition on natural levees and the planting of more salt-tolerant vegetation on natural levees.
\end{abstract}

Keywords: river delta; sedimentation; complexity; Phragmites; D-Flow FM

\section{Introduction}

Wetland vegetation in river floodplains and deltas responds to water flow and sediment deposition but also modifies water flow and sediment deposition. Studies have shown that bank strength and erodibility of a fluvial channel are modified by plant roots [1] and that vegetation stems create nonuniform lateral discharge from channels even under median and low-discharge conditions [2]. Roseau Cane (Phragmites australis (Cav.) Trin. ex Steud.) is widely distributed globally in temperate and subtropical wetlands. In the fall of 2016, wetland managers noticed that P. australis was dying in the Mississippi River Bird's Foot Delta (see Figure 1), also known as the Balize Delta [3]. By the spring of 2017, P. australis dieback in the Bird's Foot Delta was apparent to recreational fishers and then was noted in the popular press. By the summer of 2017, researchers had begun visiting selected 
sites to collect data and samples that could be used to track changes in the abundance of an insect (Roseau Cane Scale; Nipponaclerda biwakoensis) that is native to Asia and appears to coincide with the dieback [4].

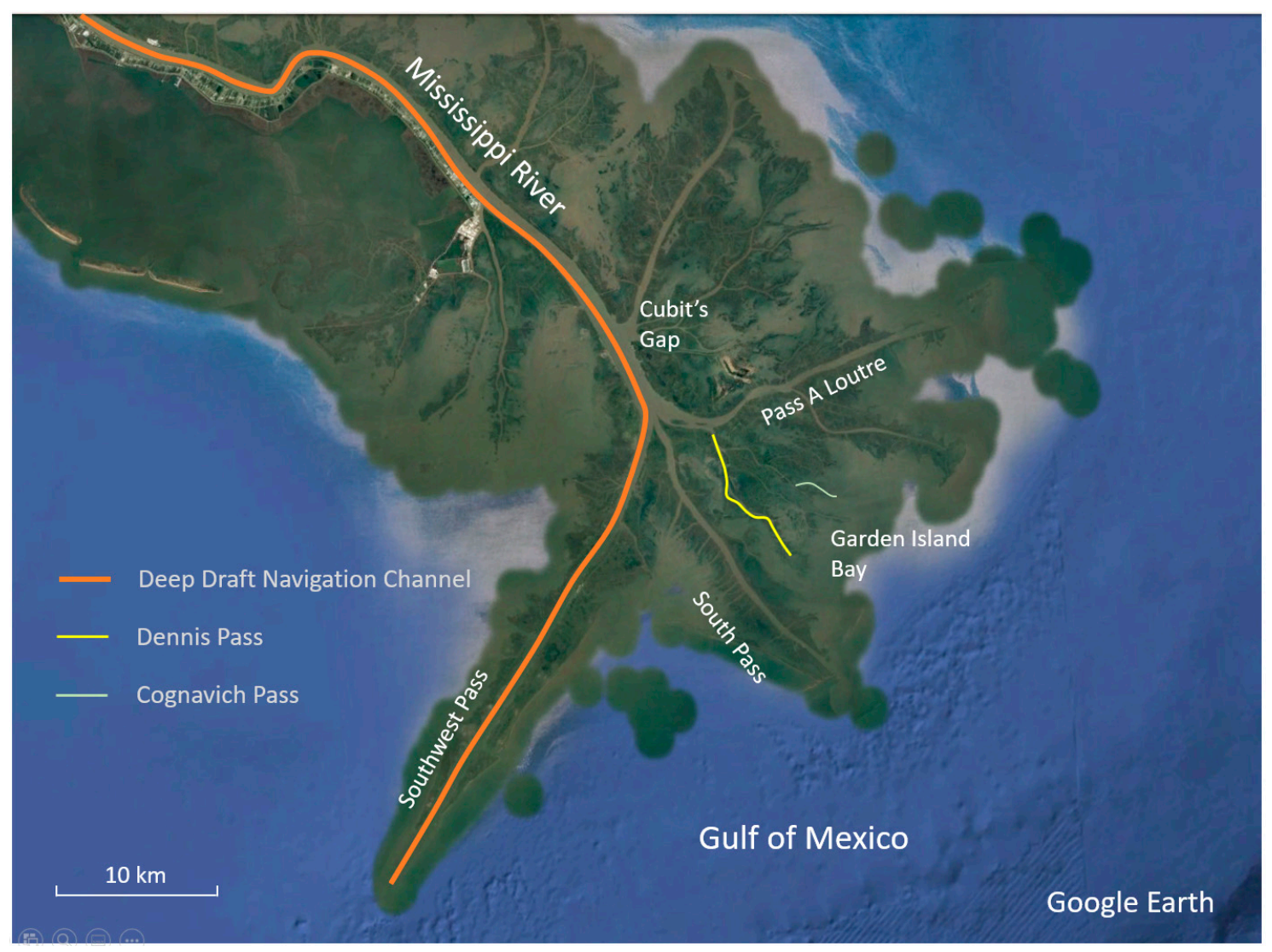

Figure 1. The Lower Mississippi River and the Bird's Foot Delta comprised of numerous, branching distributary channels. One is dredged to allow deep draft, ocean-going vessels. Examples of smaller distributary channels are indicated in the Garden Island Bay subdelta showing Dennis Pass, which began building this subdelta in 1891, and Cognavich Pass. Dennis Pass originates from Pass A Loutre and is approximately 11,700-m long (150-m wide); Cognavich Pass is approximately 2000-m long 20-m wide.

Wildlife managers throughout most of North America would welcome P. australis dieback (e.g., [5]), because a European variety of P. australis that was limited to the New England region of North America before 1910 [6] began replacing a New England variety of P. australis and other native wetland species throughout Canada and the Northern U.S. in the mid- to late-1900s [7]. On the Gulf Coast of North America at the Bird's Foot Delta, however, $P$. australis was considered native rather than one of the exotics recognized in the 1890s [8], and at least two varieties there predate the arrival of the European variety sometime after the early-1990s [9]. The spread of those varieties, subsequently named Delta and Gulf [10], in the 1900s probably is not associated with the invasion by the European variety. Instead, the species that dominated the first decade after the sediments become subaerial, such as Schoenoplecutus deltarum, Colocasia esculenta, and Sagittaria spp. [11], appeared to be outcompeted by taller perennials such as Schoenoplectus californicus, Zizaniopsis milacia, and P. australis several decades after the sediments became subaerial (personal observation, J.A. Nyman). Marsh vertical accretion slows as plant communities mature [12], but regional deep subsidence continues, which probably favors $P$. australis over the other tall perennials because its internal gas transport benefits from humidity- and Venturi-induced convections [13]. The occasional tropical storms probably also favor P. australis, because it is more salt-tolerant than those other tall perennials. Regardless of the mechanism, P. australis replaces those perennials as the expanding delta splay obstructs river discharge, ceases 
expanding, continues to subside, and is exposed to more salinity stress [14]. The European variety of $P$. australis is easily distinguished from the Gulf and Delta varieties, because the European variety is significantly shorter [15] and has broader, darker leaves (personal observation, J.A. Nyman). Its arrival at the Bird's Foot Delta is uncertain, but Hauber et al. [9] reported that it was after the mid-1990s and one of us (J.A. Nyman) familiar with the vegetation there in the 1980s first observed the European variety there in the early 2000s. The Bird's Foot Delta also supports small amounts of a fourth variety; discussions of P. australis in the Bird's Foot Delta are further complicated by the evolving terminology: subspecies, variety, type, haplotype, genotype, and phenotype. Achenback and Brix [15] summarized the recent understandings as "each of these four types is a distinct haplotype, identified based on chloroplast DNA [16] as haplotypes I2 (Land-type), M1 (Delta-type), M (EU-type), and AI (Greeny-type). New evidence [10], however, distinguishes between haplotype M and haplotype M1 (Delta-type), which is actually the dominant phenotype in the Gulf Coast today."

Extensive stands of P. australis in the Bird's Foot Delta buffer desirable wildlife habitats on mud flats from salinity and waves in the Gulf of Mexico while growing in water too deep for mud flat species to tolerate. That deep water Roseau also buffers oil and gas infrastructures and recreational camps from maritime waves. P. australis also dominates the highest elevations in the natural levees, where it appears superior to other wetland plant species at trapping the sediment, strengthening the channel banks in distributary passes, and at restricting the lateral flow from distributary passes (Figure 2). By limiting the flow through numerous distributary passes, P. australis on natural levees thus appears to increase the flow in the deep draft navigation channel, as vegetation has been shown to slow bank erosion and restrict the lateral flow in other deltas [1], which, in turn, may reduce the costs of navigation dredging. The dieback of $P$. australis thus may shorten the lifespan of subdeltas, by accelerating their degradation and then delaying the development of new subdeltas, which typically span less than 200 years [17].

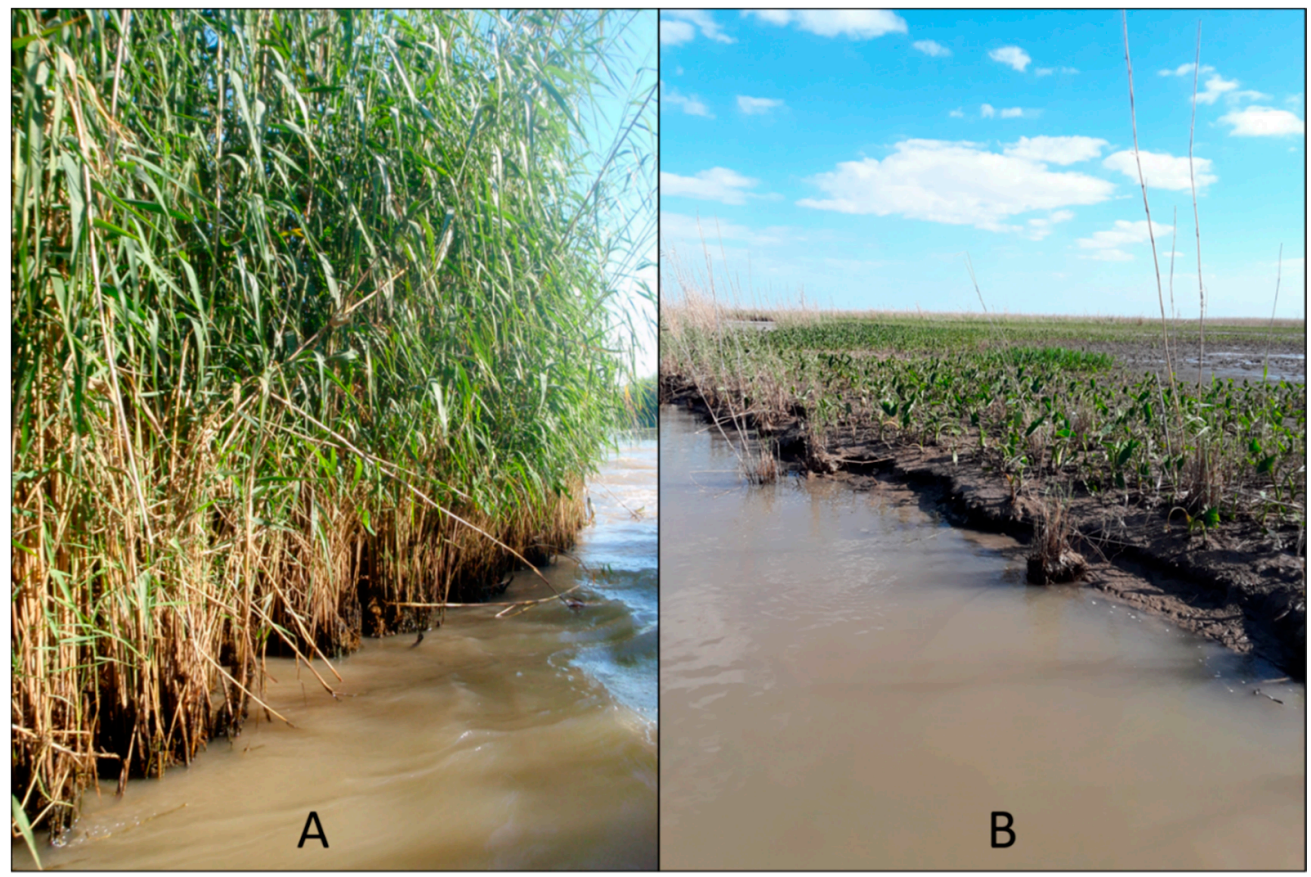

Figure 2. Some channel banks in the Bird's Foot Delta of the Mississippi River before and after Phragmites dieback. (A) Photo taken in 2010 several years before Phragmites dieback began. Then, the roots and stems appeared dense and strong. (B) Photo made in 2021 after several years of Phragmites dieback. After dieback, in addition to the loss of height, the roots and stems appear less dense and less resistant to erosion and lateral flow. Both photos are from the Pass A Loutre Wildlife Management Area. 
Commodities and products that are shipped across the world are affected by the costs of dredging to maintain the navigation channel in the Lower Mississippi River. The costs of dredging within the Bird's Foot Delta exceed 30 million $\$$ year $^{-1}$ in most years and approached 100 million $\$$ year $^{-1}$ in 2013 [18]. Recent data showed that the cost to maintain Southwest Pass was 80-100 million $\$$ year $^{-1}$ [19]. More channel sedimentation means more dredging costs. With this initial effort, there were insufficient funds to collect bathymetric data throughout the Bird's Foot Delta; to collect data on the effects of the $P$. australis belowground biomass on bank erodibility across a range of current velocities; and to collect data on the effects of P. australis stem density, diameter, and height on the lateral flow across a range of river stages and tidal stages. Thus, we could not simulate the bathymetry of the Bird's Foot Delta, the effects of $P$. australis roots on the bank strength and erodibility, or the effects of $P$. australis stems on the lateral flow. Instead, we simulated a generalized delta across a range of conditions, representing a range of $P$. australis extents and associated range of distributary channel complexity. In this generalized delta, the effects of increasing lateral flow as P. australis declines were mimicked by shortening the length of the distributary channels. Similarly, the effects of increasing erosion and channel widening as P. australis declines were mimicked by having fewer narrower channels and more wider channels. Although this study was motivated by apparent declines in the channel network of the Bird's Foot Delta caused by P. australis dieback, this study may also be relevant to changes in distributary channel networks associated with other factors such as the natural processes of delta evolution, or invasion or dieback of wetland plants other than P. australis that reduce erodibility or restrict lateral flow.

The management of this complex system is a big challenge for river managers. One question is how channel sedimentation will change due to the changing deltaic system with different channel complexities. What is the relationship between the channel complexity and sedimentation? For example, as shown in Figure 3, will it be linear or nonlinear? This is an important question for river managers, because if the relationship is linear, then a given amount of change in the channel complexity always can be expected to have the same effect on navigation dredging, and river managers can be confident that their efforts will have a similar effect regardless of channel complexity (Figure 3A). However, if the relationship is nonlinear (Figure 3B,C), then a given amount of loss or restoration in the channel complexity will cause trivial changes in navigation dredging at some levels of the channel complexity but a significant amount of change in navigation dredging at other levels of the channel complexity. Likewise, efficient managers may need to change dredging more in response to some changes in channel complexity than to others.

A

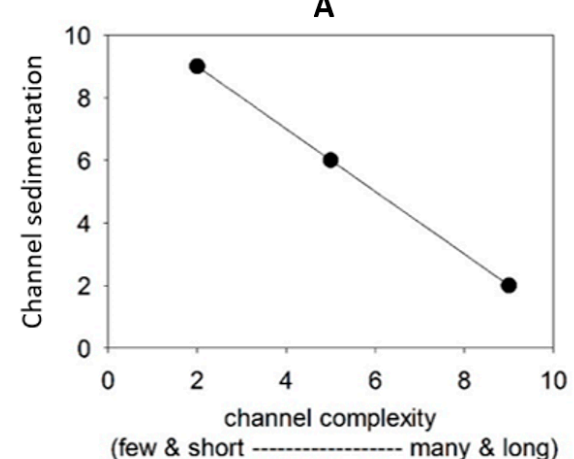

B

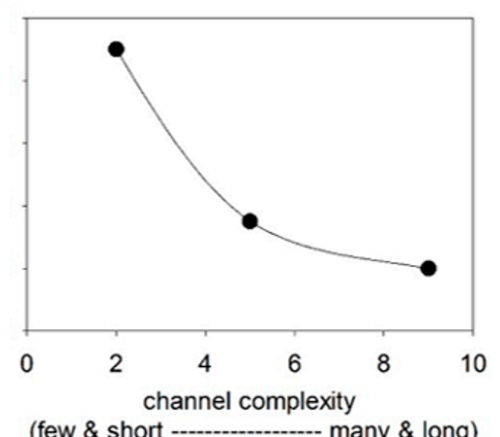

C

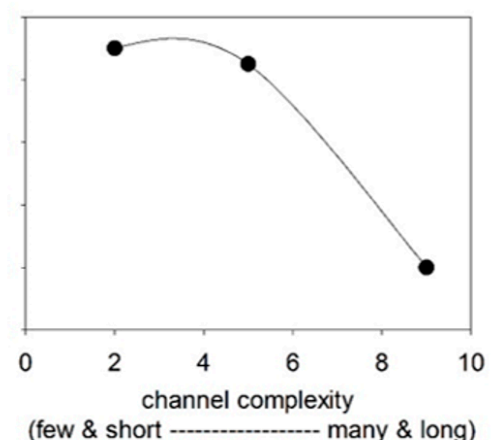

Figure 3. Possible relationships between the channel complexity and sedimentation. In (A), river managers can be confident that a given change in delta complexity always will require a similar change in navigation dredging. In (B), river managers could expect little change in navigation dredging as channel complexity changed from 7 to 10 (delta building), or vice versa (delta degradation), but could expect large changes in navigation dredging as channel complexity changed from 2 to 5 (delta building), or vice versa (delta degradation). Likewise for (C) but in that situation, sedimentation is less sensitive to channel complexity in simple deltas but is more sensitive to channel complexity in complex deltas. 
In this study, a simple complexity index was proposed to quantify the topologic channel complexity across a wide range of channel complexities. A series of idealized delta configurations with comparable spatial scales to the channels in the Bird's Foot Delta were designed to represent different extents of the distributary channels. We then applied an open-sourced process-based model program, Delft3D-Flow Flexible Mesh (D-Flow FM), to each delta configuration for simulations of hydrodynamics, sediment transport, and decadal morphological changes under the forces of riverine input and offshore tides. Moreover, the physical processes (e.g., tide, wind, waves, sea level rise, water hydrographs, and sediment supply) were further explored to understand the system response to the distributary channel complexity.

\section{Methodology}

\subsection{Conceptual Multichannel Deltaic Systems}

Figure 4 shows the evolution of the Cubit's Gap subdelta, which began in 1862 [17]. The area evolved from a simple deltaic system with a few and short channels to a complex deltaic system with many lengthy channels. Different degrees of $P$. australis dieback can be represented by different landscapes. In these landscapes, emergent vegetation was limited to subaerial portions of the delta, which grew and subsided during the last two centuries (Figure 4). P. australis dominates the oldest stages of delta development in the Bird's Foot Delta [11]. Four landscapes with different degrees of subaerial extent, i.e., different degrees of emergent vegetation; the different degrees of $P$. australis extent were categorized in this study as follows:

(i) Extensive P. australis. In this landscape, the discharge is constrained by long, narrow channels that bifurcate repeatedly. This landscape is intended to represent conditions similar to what in the Bird's Foot Delta has occurred in Main Pass from 1922 to the present [8] that may persist if $P$. australis dieback is a temporary phenomenon (Figure $4 \mathrm{D}-\mathrm{F}$ ).

(ii) Minimum P. australis extent. In this landscape, the discharge is constrained only by short, wide channels that rarely bifurcate. This landscape is intended to represent conditions similar to what occurred in Main Pass during 1884 [17] that may occur again if $P$. australis dieback is extreme and persistent (Figure 4B).

(iii) Poor P. australis extent. In this landscape, the discharge is constrained by channels that are approximately one-third as complex, in terms of length and bifurcation, as in condition (i). This landscape is intended to represent the conditions that occurred in Main Pass during 1905 [8] and that may occur if the P. australis dieback is fairly severe and persistent (Figure 4C).

(iv) Good P. australis extent. In this landscape, the discharge is constrained by channels that are approximately two-thirds as complex, in terms of length and bifurcation, as in condition (i) (Figure 4D-F). This landscape is intended to represent conditions that may occur if the P. australis dieback is moderately severe and persistent.

Landscapes in the years 1884, 1905, and 1971 are good examples of the minimum (ii), poor (iii), and good/extensive (iv and i) P. australis extents, respectively (Figure 4B-F). Landscapes with different $P$. australis extents were further conceptualized into multiple levels (L0 to L3) of multichannel deltaic systems. As shown in Figure 5, we designed fourlevel deltaic systems to represent the minimum (L0 and L1), poor (L2), and good/extensive (L3) P. australis extents, respectively. L0 represents a single channel. L1 is generated after L0 equally bifurcates into three subchannels at the middle of its length. If this kind of procedure iterates at all or selects outfall channels, the rest of the channel configurations can be generated. In addition to symmetric systems (L0, L1, L2a, and L3a), we also considered a few asymmetric systems (L2b, L2c, L3b, and L3c). 

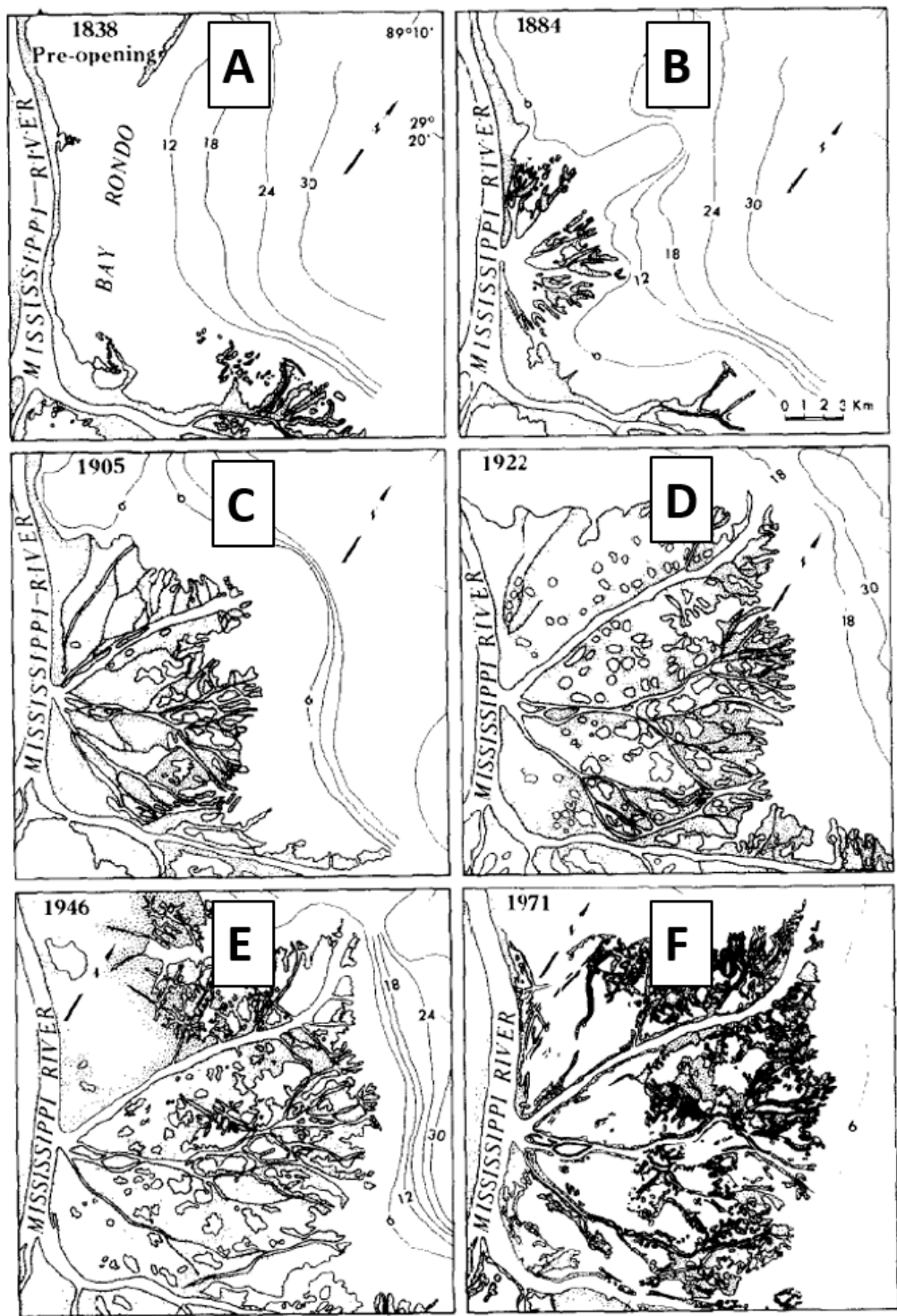

Figure 4. Sequential development of the Cubit's Gap subdelta (revised from [17]). (A) (1838) and (B) (1884) show this area before and after this subdelta began building in 1862. Throughout the early and mid-1900s (C-E), mudflats were colonized by rooted, emergent wetland plants, and natural levees formed on distributary channels, which branched, lengthened, and built new mud flats. By the mid-1900s, interdistributary basins were sediment starved as flood water generally remained confined by natural levees and associated vegetation. By 1971 (F), distributary channels were near their maximum extent because natural levees supported extensive stands of woody vegetation (upstream) and Phragmites australis (downstream).

The multichannel system becomes more and more complex from L0 to L3. Two types of complexity have been quantified for river delta networks [20] - that is, topologic complexity, imposed by the network connectivity and dynamic complexity, dictated by the flux partitioning and distribution. We focused on topologic complexity in this study. Inspired by reference [20], a simple expression of the channel complexity index for idealized deltaic systems in this work can be expressed as:

$$
\text { Complexity Index }=\ln (\mathrm{NL} \times \mathrm{NV} \times \mathrm{NO})
$$

where NL is the number of links, NV is the number vertices, and NO is the number of outlets. As shown in Table 1, the complexity index varies from 0 for L0 to 9.3 for L3a. 
LO
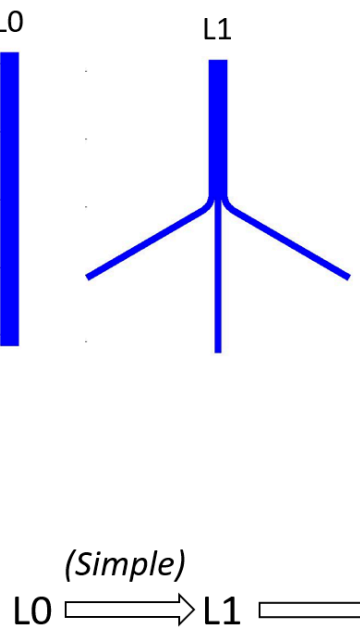

Minimum P. australis extent
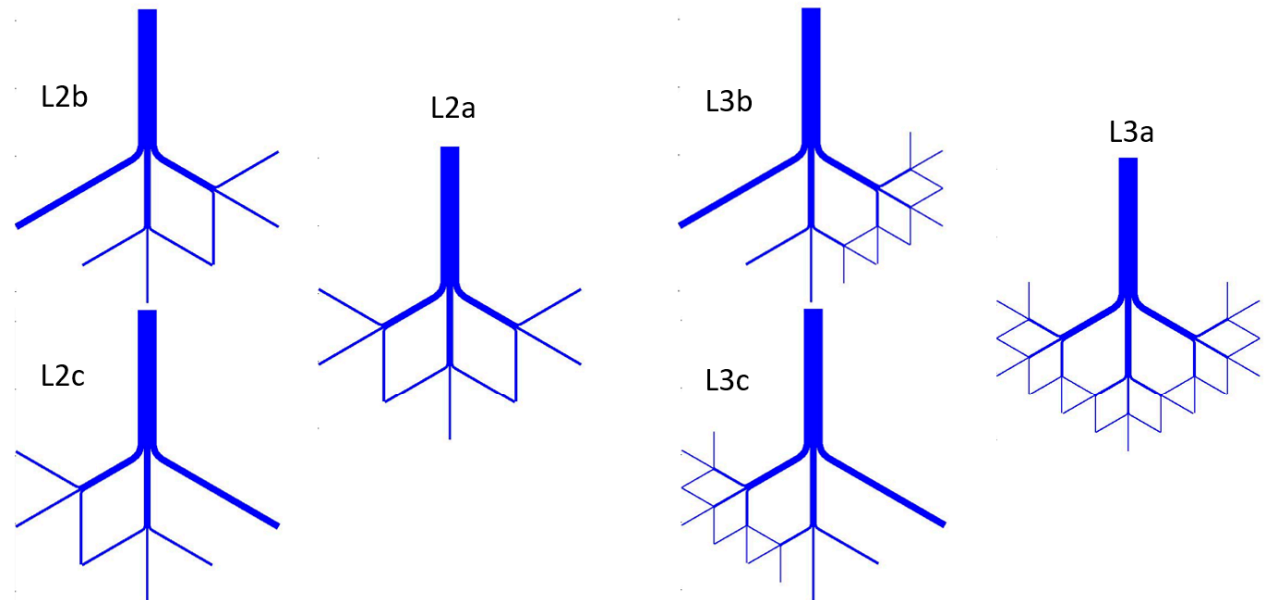

(More complex) $\rightarrow \mathrm{L} 3$

Good/extensive P. australis extent

Figure 5. Multiple levels of multichannel deltaic systems.

Table 1. Summary of the complexity index and topologic characteristics of each idealized deltaic system.

\begin{tabular}{ccccc}
\hline Level & NL (\# of Links) & NV (\# of Vertices) & NO (\# of Outlets) & Complexity Index \\
\hline L0 & 1 & 1 & 1 & 0 \\
L1 & 3 & 1 & 3 & 2.2 \\
L2b/L2c & 9 & 3 & 7 & 5.2 \\
L2a & 12 & 4 & 9 & 6.1 \\
L3b/L3c & 20 & 7 & 13 & 7.5 \\
L3a & 36 & 13 & 23 & 9.3 \\
\hline
\end{tabular}

\subsection{Conceptual Multichannel Process-Based Model}

A process-based hydrodynamic, sediment, and morphological model was applied to multichannel deltaic systems to compare the sedimentation under the same hydrodynamic and sediment conditions. This kind of conceptual model has been widely used for mechanism research, such as the development of delta distributary networks [21] and the effect of the median grain diameter $\left(\mathrm{D}_{50}\right)$ on the formation of a delta channel network [22] The purpose of this study, however, was not to model delta evolution (e.g., from L0 to L3) with the influence of $P$. australis. As stated earlier, different multichannel deltaic systems can represent different $P$. australis extents. The channel configuration was fixed in one deltaic system. In other words, bank erosions and lateral flows were not allowed. Instead, the sedimentation and morphological changes within the channels due to factors, such as river discharge, tide, wind, and waves, were calculated. For consistency in the comparisons, the areas of all the channels in each deltaic system were unchanged. In addition, distributary channels were not prioritized. The model results were summed up over all the channels in one system for comparison. A higher sedimentation means more efforts (dredging) to maintain navigation channels in this system, which can indicate the effect of the corresponding P. australis extent.

The Delft-Flexible Mesh [23], also known as D-Flow Flexible Mesh (D-Flow FM), was a suitable numerical tool for this study. It has been widely used for modeling tides [24], storm surge [25], inundation [26], saltwater intrusion [27], sediment dynamics [28], sediment budget [29], etc. The software is an open-source multidimensional (one-, two-, and three-dimensional) hydrodynamic and transport simulation program developed by Deltares of the Netherlands. It can carry out simulations of flow hydrodynamics, salinity, temperature, sediment transport, and morphological change for coastal, river, and 
estuarine areas. D-Flow FM solves the shallow water equations with finite volume numerical schemes. It uses a combination of curvilinear and unstructured grids to adapt highly complex geometries/bathymetries. The morphology processes can be accelerated by using a morphological scale factor (Morfac) under normal time-scale hydrodynamic flow conditions. It also has the capability to couple with wave computation.

Based on D-Flow FM, a conceptual multichannel model was developed for simulations of the hydrodynamics, sediment transport, and long-term morphological changes in a series of idealized deltaic systems with different channel complexities. In order to match the physical situation in the Bird's Foot Delta, we scaled the designs in Figure 4 according to the actual channel dimensions. We set a simple channel with $21,600 \mathrm{~m}$ in length (len0) and $1350 \mathrm{~m}$ in width (wid0) for L0. The subchannels in L1 were len $0 / 2$ in length and wid0/3 in width-that is, $10,800 \mathrm{~m}$ and $450 \mathrm{~m}$, respectively. The smallest channels in L3 were $2700 \mathrm{~m}$ in length (len0/8) and $50 \mathrm{~m}$ in width (wid0/27). This scaling was consistent with the width of the draft navigation channel (see Figure 1), which varies from $1.5 \mathrm{~km}$ near the Head of the Passes to $600 \mathrm{~m}$ in the Southwest Pass. It also very closely mimicked the length of the distributary channels in the subdeltas, such as the Dennis Pass that began forming during 1891 in Garden Island Bay, but was wider than the actual channels (e.g., the Cognavich Pass) in the modern Bird Foot Delta (Figure 1). An unstructured curvilinear-like mesh was generated for each conceptual deltaic system by a tool called "RGFRID” in Delft3D [30]. The grid resolution was $20 \mathrm{~m}$ along the channel and $10 \mathrm{~m}$ across the channel for each mesh everywhere except the junction areas, where the resolution was higher. This guarantees five grids across the tiniest channels in L3. Figure 6 shows an example of the mesh generated for L3a. It consists of 144,500 elements and 150,838 nodes. Other meshes have similar numbers of elements and nodes. The enlarged local area demonstrates a perfect mesh quality in terms of orthogonality and smoothness that are required by D-Flow FM.

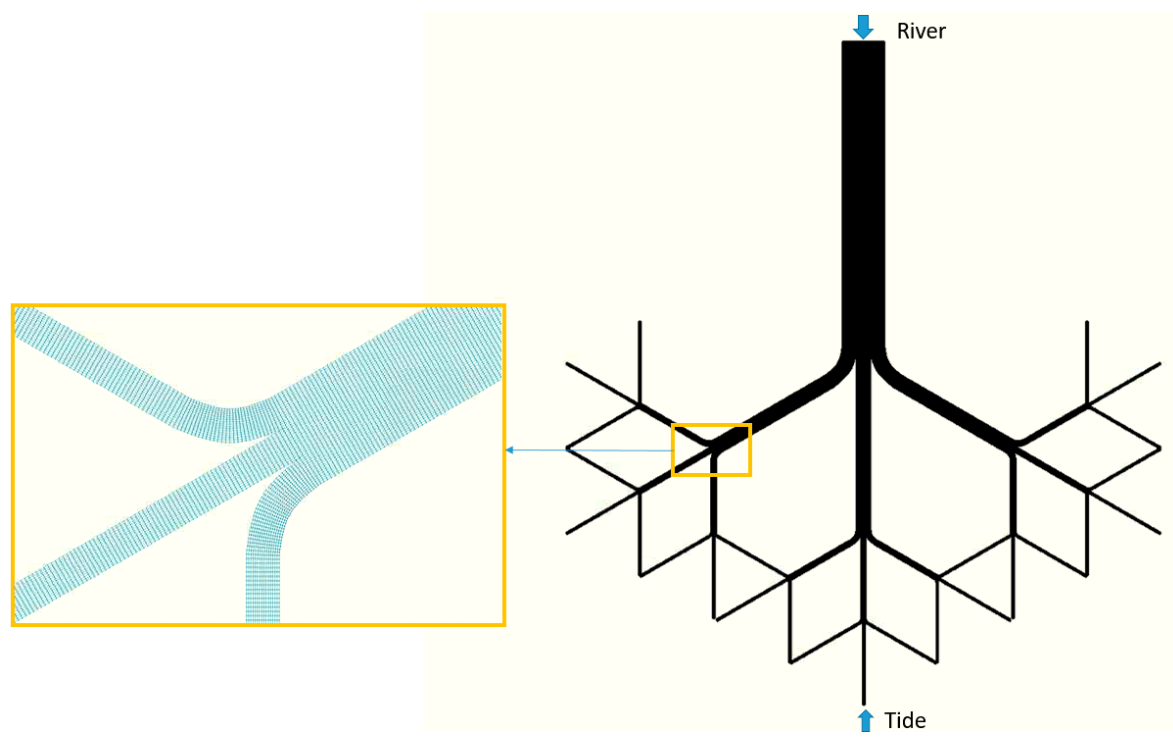

Figure 6. An unstructured mesh generated for L3a.

A uniform bed level ( $8 \mathrm{~m}$ below NAVD 88) was selected for each deltaic system. A constant river discharge $\left(10,800 \mathrm{~m}^{3} / \mathrm{s}\right)$ - that is, $1 \mathrm{~m} / \mathrm{s}$ in the current velocity, equivalently, was added at the north boundary (see Figure 6). At each outlet, the tide was applied by observed amplitudes and phases of harmonic tidal constituents from Grand Isle, LA (NOAA tidal Station 8761724). The $\mathrm{D}_{50}$ for the sand was $150 \mu \mathrm{m}$. The suspended sand concentrations at the river boundary and at the outlets were $50 \mathrm{mg} / \mathrm{L}$ and $0 \mathrm{mg} / \mathrm{L}$, respectively. The values for the sand grain size and river suspended sand concentration were both representative in the ranges observed in the bed and suspended load within the lower Mississippi River [31]. 
The formula of van Rijn [32] was adopted for sediment transport. Morfac was set to 20 for the acceleration of the morphology processes. The time step was about $6 \mathrm{~s}$, which varied during the run and was determined by the Courant-Friedrichs-Lewy condition [33].

\section{Results}

Figure 7 shows the distributions of the bed level changes after 10 years for each deltaic system under the same forces of river discharge and tide. Compared with the other complex systems, both sedimentation and erosion were the mildest in the simplest system of L0. The morphological changes were extremely active near the junction areas where the current velocity varied greatly. It seems that heterogeneous sedimentation/erosion patterns tend to appear in wide channels (e.g., subchannels right after the first bifurcation), while the narrow channels (e.g., outfall channels in L3a) were inclined to have homogeneous distributions, showing either sedimentation or erosion.

To test the effects of symmetry, we designed asymmetrical systems for L2 and L3. The sedimentation/erosion patterns in the more complex sides of L2b and L2c were almost identical to those in the corresponding side of L2a, which means the symmetry had little effect on the L2 systems. On the other hand, compared with L3a, substantial difference appeared in the more complex sides of L3b and L3c, and the effect of asymmetry was obvious for the L3 systems. Moreover, we carried out an additional run for L1 by switching off the Coriolis force. The results turned out to be perfectly axisymmetric, which implies that the effect of the Coriolis force is significant in redistributing sediments among different subchannels, and it should not be ignored.

To examine how each deltaic system evolves for 10 years, we calculated the total sedimentation in metric million tons (MMT) by spatially summing up the sedimentation mass at all mesh elements of each system. A time series of modeled total sedimentation is shown in Figure 8 (left subfigure). All the deltaic systems appeared to have a similar trend that showed the erosion at the beginning and gradually accumulated sediment for the rest of the period. Eight curves can be categorized into three groups: Group 1 includes L0, L1, L2a, L2b, and L2c; Group 2 includes L3b and L3c; and Group 3 has L3a only. Within each group, their delta evolution in terms of the total sedimentation was almost identical, especially for the first five years. The sedimentation capacity declined for the more complex systems from Group 1 to Group 3. Figure 8 (right subfigure) also shows the modeled relationships between the channel complexity and sedimentation in Year 1, Year 5, and Year 10.

All the curves (Figure 8) matched very well with our third relationship assumption in Figure 3C: the resulting relationship was nonlinear, such that the sedimentation was less sensitive to the channel complexity when the channel complexity was low but was more sensitive to the channel complexity when the channel complexity was high. The total sedimentation appeared stable until the channel complexity index reached 6 in the short term, i.e., five years and less, but differences appeared afterwards (Figure 8) As the channel complexity increased beyond 6 , the total sedimentation decreased rapidly even in the short term, which would benefit navigation dredging. Since the channel complexity was probably related with the degree of $P$. australis extent, these results suggest that navigation dredging was probably more sensitive to P. australis dieback in the existing, complex Bird's Foot Delta than it will be in future years when the channel complexity decreases because of $P$. australis dieback and other factors, such as sediment starvation, subsidence, and sea-level rise, that are contributing to delta backstepping [34]. The symmetry effects indicated by our model, systems L2b vs. L2c, (Figures 7 and 8) suggests that changes in distributary channels on the east side of the Bird's Foot Delta have a greater impact on sedimentation than channels on the west side. 


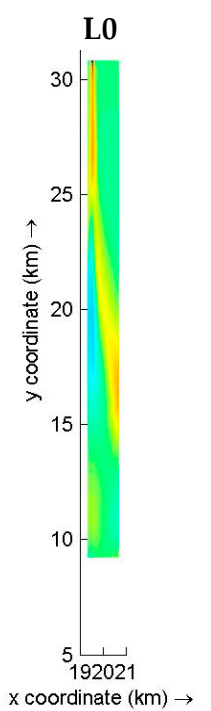

L2a

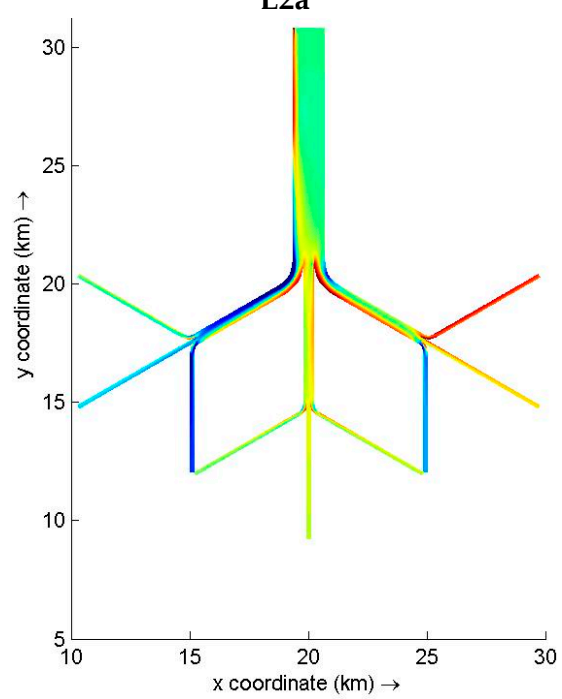

L3a

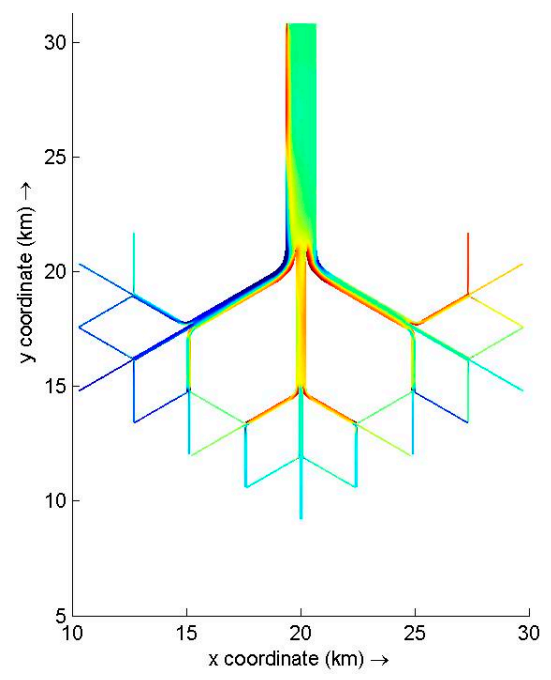

L1

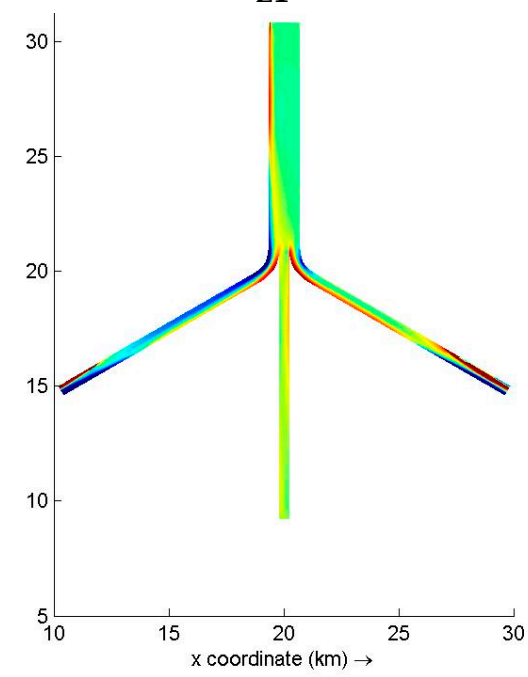

L2b

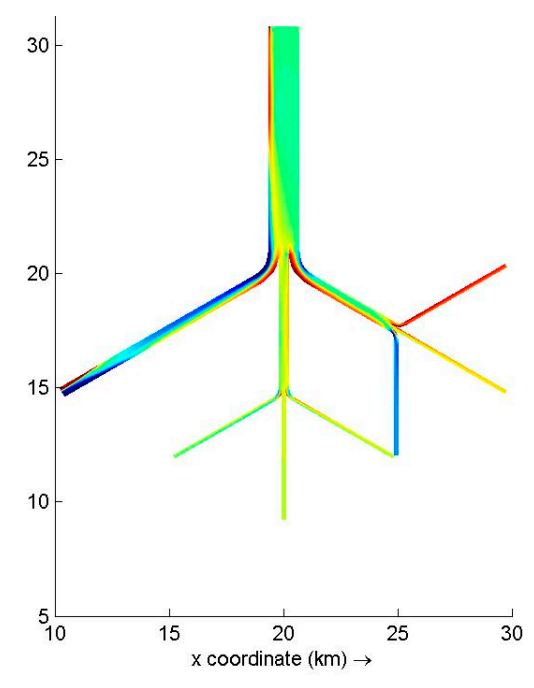

L3b

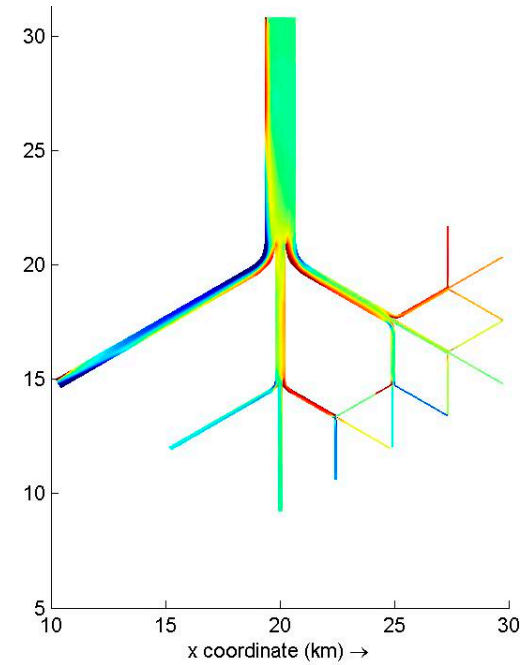

L1 (no Coriolis force)

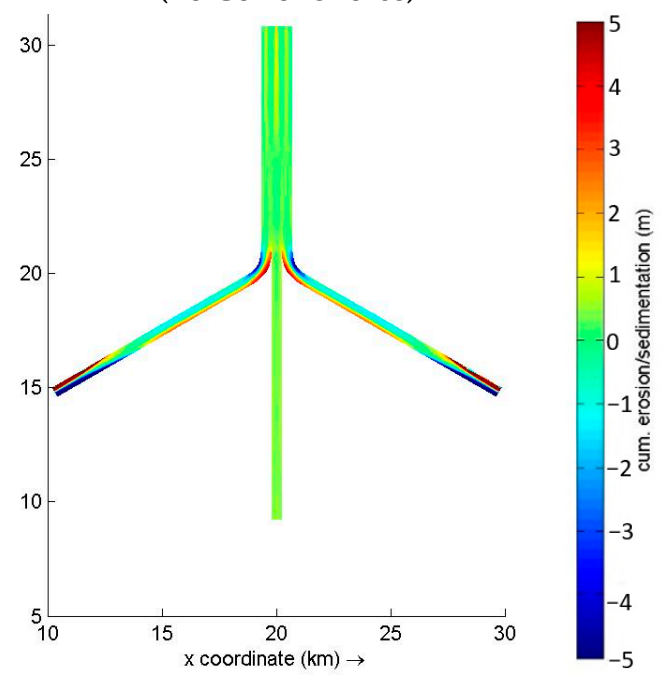

L2c

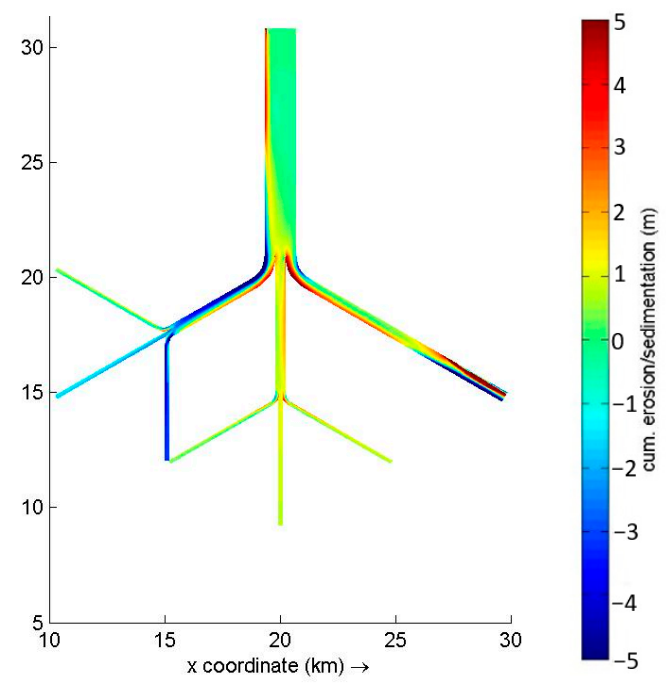

L3c

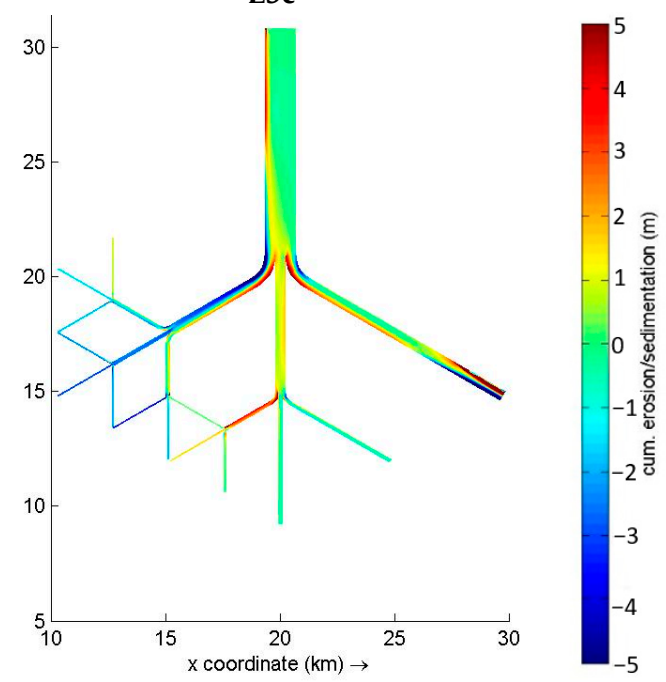

Figure 7. Bed level changes after 10 years for each deltaic system. 


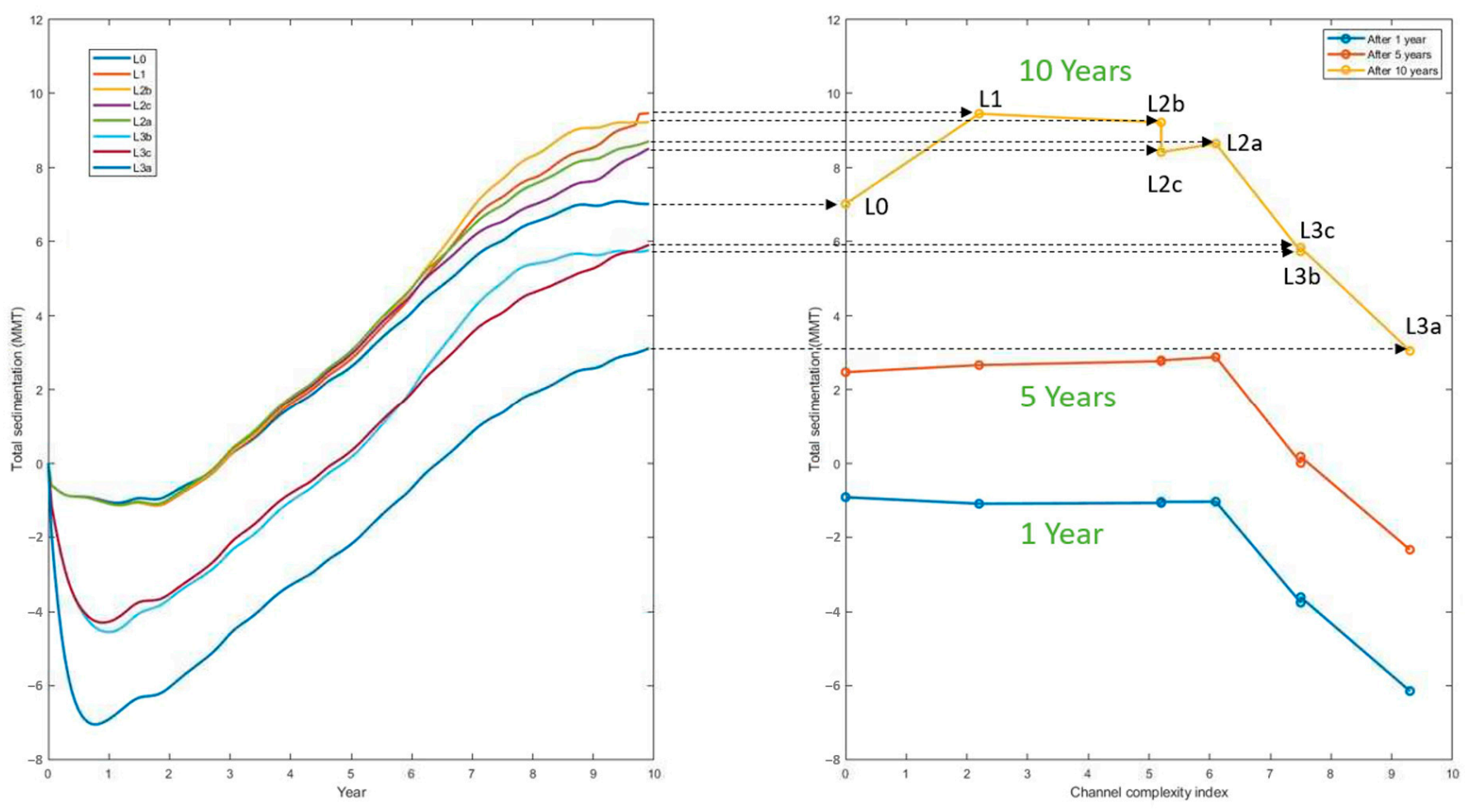

Figure 8. Time series of the total sedimentation (MMT) for each deltaic system (left subfigure), and the total sedimentation vs. channel complexity in Year 1, Year 5, and Year 10 (right subfigure).

\section{Sensitivity Analysis}

Further sensitivity tests were carried out to investigate how various physical processes/factors affected the model results. We selected one deltaic system (L2a) as an example and did a series of tests by switching on/off factors or adjusting their values. As listed in Table 2, 13 tests (see Option 1 and Option 2) were completed for eight processes/factors. A time series of the total sedimentation in the base case and in these 13 tests are shown in Figure 9.

- Tide: With no tides, the sedimentation rate, compared with the base case, increased for the first several years but then decreased afterwards. Interestingly, the final sedimentation was very close to the base case with the tide turned on. The tide affected the evolution of the system, but this effect diminished over decades.

- Wind: There was no significant difference between the wind case and the base case with no wind. It seems that the normal wind fields (excluding extreme events such as hurricanes and cold fronts) have little effect on long-term sedimentation processes.

- Waves: The effect of the waves was substantial. Both scenarios showed a reduction of sedimentation when the waves were turned on. The most likely explanation is that enhanced bottom shear stresses by the waves made the bed material more erodible.

- Sea level rise: The sea level rise caused an increase of the water level and, equivalently, a decrease of the river current speed given the same river discharge. The reduced current velocity increased the sedimentation in the system.

- River discharge: The system was very sensitive to river discharge. An increase of discharge accelerated the current, which moved more sediment out of the system and caused less sedimentation and more erosion.

- River sediment concentration: A change of the river sediment concentration changed the riverine sediment supply. It was obvious that the more sediment supply came with more sedimentation and vice versa. 
- $\quad$ Sediment median grain size $\left(\mathrm{D}_{50}\right)$ : Under the same hydrodynamic conditions, the transport rate for coarser sediments was smaller than for finer sediments, which can result in more sedimentation for coarser sediments.

- Bed level: Similar to the river discharge, the system was also very sensitive to a bed level change. Given the same river discharge, an increase in the bed level decreased the current velocity, which increased the sedimentation.

Table 2. Summary of the factor settings in different scenarios for L2a and their impacts on the sedimentation.

\begin{tabular}{|c|c|c|c|c|c|}
\hline Factor & Base Case & Option 1 & Option 2 & $\begin{array}{l}\text { Impact on } \\
\text { (Option 1) }\end{array}$ & $\begin{array}{l}\text { limentation } \\
\text { (Option 2) }\end{array}$ \\
\hline Tide & On & Off & / & Neutral & / \\
\hline Wind $^{1}$ & Off & On & / & Neutral & / \\
\hline Waves $^{2}$ & Off & On (Fetch/depth limited) & On (Young-Verhagen) & Decrease & Decrease \\
\hline Sea level rise ${ }^{3}$ & Off $(0 \mathrm{~m})$ & On $(+0.2 \mathrm{~m})$ & / & Increase & / \\
\hline River discharge & $10,800 \mathrm{~m}^{3} / \mathrm{s}$ & $12,960 \mathrm{~m}^{3} / \mathrm{s}(+20 \%)$ & $8640 \mathrm{~m}^{3} / \mathrm{s}(-20 \%)$ & Decrease & Increase \\
\hline $\begin{array}{l}\text { River sediment } \\
\text { concentration }\end{array}$ & $50 \mathrm{mg} / \mathrm{L}$ & $60 \mathrm{mg} / \mathrm{L}(+20 \%)$ & $40 \mathrm{mg} / \mathrm{L}(-20 \%)$ & Increase & Decrease \\
\hline D50 & $150 \mu \mathrm{m}$ & $160 \mu \mathrm{m}$ & $140 \mu \mathrm{m}$ & Increase & Decrease \\
\hline Bed level & $8.0 \mathrm{~m}$ & $9.6 \mathrm{~m}(+20 \%)$ & $6.4 \mathrm{~m}(-20 \%)$ & Increase & Decrease \\
\hline
\end{tabular}

${ }^{1}$ Observed 2018 wind data at Grand Isle, LA (NOAA tidal Station 8761724) was applied. ${ }^{2}$ Option 1 and Option 2 are two empirical wave model options available in D-Flow FM. ${ }^{3}$ Applied as A0, in addition to other astronomical components, at each outlet.
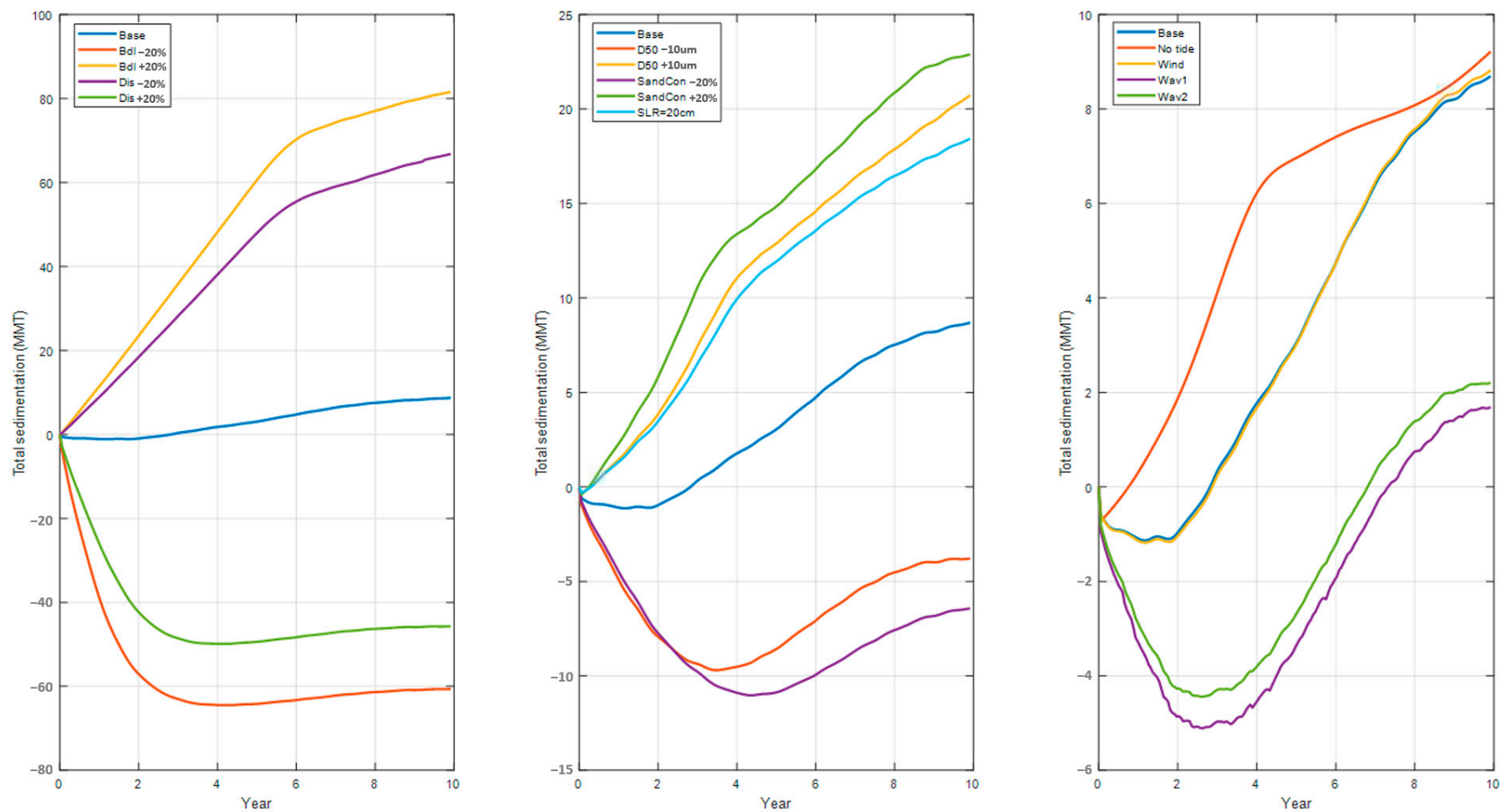

Figure 9. Time series of the total sedimentation (MMT) with various factor settings for L2a. Note that the three subfigures have different vertical scales.

Through these sensitivity tests, we concluded that, as shown in Figure 9, the system is extremely sensitive to the discharge and bed level (left subfigure); very sensitive to the sea level rise, river sediment concentration, and $\mathrm{D}_{50}$ (middle subfigure); and less sensitive to the tide and waves (right subfigure). Their impacts on navigation are summarized in Table 2. Overall, the physical processes that could benefit navigation dredging include more wave 
energy, less sea level rise, more river discharge, a lower river sediment concentration, finer sediment grain sizes, and shallower bed levels.

\section{Conclusions}

Based on D-Flow FM, a 2D conceptual multichannel model was developed and applied to a series of idealized deltaic systems with different channel complexities for simulations of hydrodynamics, sediment transport, and decadal morphological changes under the forces of the riverine discharge and offshore tide. A simple expression was proposed to quantify their channel complexity. Examining the modeled sedimentation results for various scenarios suggested that the increase of the delta topologic complexity decreases the channel sedimentation and, thus, might benefit navigation dredging. The relationship between delta complexity and channel sedimentation is nonlinear. For less complex systems, the total sedimentation remains stable, while, for complex deltaic systems, such as the current Bird's Foot Delta, the total sedimentation decreases rapidly. Furthermore, sensitivity tests were carried out to investigate the effects of various physical processes/factors on an idealized deltaic system (L2a). The system was extremely sensitive to the discharge and bed level; very sensitive to the sea level rise, river sediment concentration, and $\mathrm{D}_{50}$; and less sensitive to the tide and waves. In this preliminary work, we used a conceptual model to study the effects of $P$. australis dieback on sediment transport and navigation dredging. Our results indicated that models of sedimentation in the navigation channel of the Bird's Foot Delta that can account for detailed bathymetry, the effects of P. australis dieback, and the effects of various restoration procedures may help river managers decide how to maintain deep draft navigation most efficiently in the Lower Mississippi River. For instance, perennial species such as Zizaniopsis milacia and Schoenoplectus spp. appear to be failing to replace P. australis throughout much of the Bird's Foot Delta (e.g., Figure 2). Those species have stronger soils than P. australis [35], but apparently, the flooding and salinity stresses are too great for those species to recolonize the areas where $P$. australis dominated before the dieback began. Perhaps a thin layer of sediment deposition could be used to increase the surface elevation where recolonization by those species is hindered by flooding stress. Perhaps Avicennia germinans could be planted where recolonization by those species is hindered by salinity stress.

Our findings do not alter the basic ideas of the deltaic cycles summarized by reference [17] but contribute to the understanding of how sediment retention within a delta changes during the cycle as a delta submerges by suggesting that sediment transport to the receiving basin changes can remain relatively stable despite large changes in the delta complexity during some stages of submergence but can change rapidly, with small changes in complexity during other stages of submergence. These ideas may be limited to deltas where further progradation of the active delta is limited by the depth of the receiving basin, such as where the Mississippi River pours into the Gulf of Mexico.

Most river deltas around the globe have experienced adverse conditions due to natural and anthropogenic factors. Sea level rises and high rates of land subsidence are the leading causes for land loss in most deltaic systems. Further, upstream river management (e.g., dams, levees, and reservoirs) has resulted in a drastic reduction in the sediment load and hydrologic disconnection between riverine systems and their adjacent estuaries [36-39]. Restoration efforts have attempted to ameliorate or at least reduce these negative impacts. However, the knowledge of the processes governing these deltaic systems (e.g., hydrodynamics, morphology, and vegetation dynamics) and incorporating such knowledge into predictive tools is vital to explore the efficacy of these restoration strategies.

Author Contributions: Conceptualization, J.A.N. and E.M.; methodology, E.M. and K.H.; software, K.H.; validation, K.H.; formal analysis, K.H.; investigation, K.H.; data curation, K.H.; writingoriginal draft preparation, K.H.; writing—review and editing, K.H., E.M., and J.A.N.; visualization, K.H. and J.A.N.; supervision, E.M.; project administration, E.M.; and funding acquisition, J.A.N. All authors have read and agreed to the published version of the manuscript. 
Funding: This project was funded in part by the Louisiana State University Agricultural Center, Louisiana Department of Wildlife and Fisheries, Louisiana Department of Agriculture and Forestry, Louisiana Coastal Protection and Restoration Authority, Coastal Wetlands Planning, Protection and Restoration Act, and the United States Department of Agriculture-Animal and Plant Health Inspection Service. This research was also supported by the National Institute of Food and Agriculture, U.S. Department of Agriculture, under award number LAB94471. It was also supported, in part, by the 2020 Tulane Carol Lavin Bernick Faculty Grant Program (LBGrants Program).

Institutional Review Board Statement: Not applicable.

Informed Consent Statement: Not applicable.

Data Availability Statement: Not applicable.

Acknowledgments: This research was supported, in part, by using high-performance computing (HPC) resources and services provided by both the Louisiana Optical Network Infrastructure (LONI) and Technology Services at Tulane University.

Conflicts of Interest: The authors declare no conflict of interest.

\section{References}

1. Kleinhaus, M.G.; van Dijk, W.M.; van de Lageweg, W.I.; Hoyal, D.C.; Markies, H.; van Maarseveen, M.; Roosendaal, C.; van Weesep, W.; van Breemen, D.; Hoendervoogt, R.; et al. Quantifiable effectiveness of experimental scaling of river- and delta morpholdynamics and stratigraphy. Earth-Sci. Rev. 2014, 133, 43-61. [CrossRef]

2. Hiatt, M.; Passalacqua, P. What controls the transition from confined to unconfined flow? Analysis of Hydraulics in a coastal river delta. J. Hydraul. Eng. 2017, 143, 03117003. [CrossRef]

3. Knight, I.A.; Wilson, B.E.; Gill, M.; Aveles, L.; Cronin, J.T.; Nyman, J.A.; Schneider, S.A.; Diaz, R. Invasion of Nipponaclerda biwakoensis (Hemiptera: Aclerdidae) and associated Phragmites australis dieback in southern Louisiana, USA. Biol. Invasions 2018, 20, 2739-2744. [CrossRef]

4. Knight, I.A.; Cronin, J.T.; Gill, M.; Nyman, J.A.; Wilson, B.E.; Diaz, R. Investigating plant phenotype, salinity, and infestation by the Roseau Cane Scale as factors in the die-back of Phragmites australis in the Mississippi River Delta, USA. Wetlands 2020, 40, 1327-1337. [CrossRef]

5. Benoit, L.K.; Askins, R.A. Impact of the spread of Phragmites on the distribution of birds in the Connecticut tidal marshes. Wetlands 1999, 19, 194-208. [CrossRef]

6. Saltonstall, K. Cyrptic invasion by a non-native genotype of the common reed, Phragmites australis, into North America. Proc. Natl. Acad. Sci. USA 2002, 99, 2445-2449. [CrossRef] [PubMed]

7. Chambers, R.M.; Myerson, L.A.; Saltonstall, K. Expansion of Phragmites into tidal wetlands of North America. Aquat. Bot. 1999, 64, 261-273. [CrossRef]

8. Lloyd, F.E.; Tracy, S.M. The insular flora of Mississippi and Louisiana. Bull. Torrey Bot. Club 1901, 28, 61-101. [CrossRef]

9. Hauber, D.P.; White, D.A.; Powers, S.P.; DeFrancesch, F.R. Isozyme variation and correspondence with unusual infrared reflectance patterns in Phragmites australis (Poaceae). Plant Syst. Evol. 1991, 178, 1-8. [CrossRef]

10. Hauber, D.P.; Saltonstall, K.; White, D.A.; Hood, C.S. Genetic variation in the Common Reed, Phragmites australis, in the Mississippi River Delta Marshes: Evidence for multiple introductions. Estuar. Coasts 2011, 34, 851-862. [CrossRef]

11. White, D.A. Vascular plant community development on mudflats in the Mississippi River delta, Louisiana, USA. Aquat. Bot. 1993, 45, 171-194. [CrossRef]

12. Cahoon, D.R.; White, D.A.; Lynch, J.C. Sediment infilling and wetland formation dynamics in an active crevasse splay of the Mississippi River delta. Geomorphology 2011, 131, 57-68. [CrossRef]

13. Englonger, A.I. Structure, growth dynamics and biomass of reed (Phragmites australis)—A review. Flora 2009, 204, 331-346. [CrossRef]

14. O'Neil, T. The Muskrat in the Louisiana Coastal Marshes; Louisiana Department of Wild Life and Fisheries: New Orleans, LA, USA, 1949; pp. 12-18.

15. Achenback, L.; Brix, H. Can differences in salinity tolerance explain the distribution of four genetically distinct lineages of Phragmites australis in the Mississippi River Delta? Hydrobiologia 2014, 737, 5-23. [CrossRef]

16. Lambertini, C.; Mendelssohn, I.A.; Gustafsson, M.H.; Olesen, B.; Riis, T.; Sorrell, B.K.; Brix, H. Tracing the origin of Gulf Coast Phragmites (Poaceae): A story of long-distance dispersal and hybridization. Am. J. Bot. 2012, 99, 538-551. [CrossRef] [PubMed]

17. Wells, J.T.; Coleman, J.M. Wetland loss and the subdelta life cycle. Estuar. Coast. Shelf Sci. 1987, 25, 111-125. [CrossRef]

18. Kemp, G.P.; Day, J.W.; Freeman, A.M. Restoring the sustainability of the Mississippi River Delta. Ecol. Eng. 2014, 64, 131-146. [CrossRef]

19. Wingate, M. Current and Future Dredging along the Lower Mississippi River. Pdf File. 2019. Available online: https://albl.org/ wp-content/uploads/2019/12/Mark-Wingate.pdf (accessed on 17 May 2021). 
20. Tejedor, A.; Longjas, A.; Zaliapin, I.; Foufoula-Georgiou, E. Delta channel networks: 2. Metrics of topologic and dynamic complexity for delta comparison, physical inference, and vulnerability assessment. Water Resour. Res. 2015, 51, 4019-4045. [CrossRef]

21. Edmonds, D.A.; Slingerland, R.L. Mechanics of river mouth bar formation: Implications for the morphodynamics of delta distributary networks. J. Geophys. Res. 2007, 112, F02034. [CrossRef]

22. Tejedor, A.; Longjas, A.; Caldwell, R.; Edmonds, D.A.; Zaliapin, I.; Foufoula-Georgiou, E. Quantifying the signature of sediment composition on the topologic and dynamic complexity of river delta channel networks and inferences toward delta classification. Geophys. Res. Lett. 2016, 43, 3280-3287. [CrossRef]

23. Kernkamp, H.W.; van Dam, A.; Stelling, G.S.; de Goede, E.D. Efficient scheme for the shallow water equations on unstructured grids with application to the Continental Shelf. Ocean Dyn. 2011, 61, 1175-1188. [CrossRef]

24. Green, R.H.; Lowe, R.J.; Buckley, M.L. Hydrodynamics of a Tidally Forced Coral Reef Atoll. J. Geophys. Res. Ocean. 2018, 123, 7084-7101. [CrossRef]

25. Bloemendaal, N.; Muis, S.; Haarsma, R.J.; Verlaan, M.; Irazoqui Apecechea, M.; de Moel, H.; Ward, P.J.; Aerts, J.C. Global modeling of tropical cyclone storm surges using high-resolution forecasts. Clim. Dyn. 2019, 52, 5031-5044. [CrossRef]

26. Hoch, J.M.; van Beek, R.; Winsemius, H.C.; Bierkens, M.F. Benchmarking flexible meshes and regular grids for large-scale fluvial inundation modelling, Elsevier. Adv. Water Resour. 2018, 121, 350-360. [CrossRef]

27. Eslami, S.; Hoekstra, P.; Nguyen Trung, N.; Kantoush, S.A.; van Binh, D.; Duc Dung, D.; Tran Quang, T.; van der Vegt, M. Tidal amplification and salt intrusion in the Mekong Delta driven by anthropogenic sediment starvation. Sci. Rep. 2019, 9, 18746. [CrossRef]

28. Achete, F.M.; van der Wegen, M.; Roelvink, D.; Jaffe, B. How can climate change and engineered water conveyance affect sediment dynamics in the San Francisco Bay-Delta system? Clim. Chang. 2017, 142, 375-389. [CrossRef]

29. Barrera Crespo, P.D.; Mosselman, E.; Giardino, A.; Becker, A.; Ottevanger, W.; Nabi, M.; Arias-Hidalgo, M. Sediment budget analysis of the Guayas River using a process-based model. Hydrol. Earth Syst. Sci. 2019, 23, 2763-2778. [CrossRef]

30. Deltares. RGFGRID User Manual. Pdf File. 2021. Available online: https:// content.oss.deltares.nl/delft3d/manuals/RGFGRID_ User_Manual.pdf (accessed on 17 May 2021).

31. Thorne, C.R.; Harmar, O.P.; Wallerstein, N. Sediment Transport in the Lower Mississippi River; Final Report; U.S. Army Research, Development, and Standardisation Group: London, UK, 2000; p. 71. Available online: https://apps.dtic.mil/sti/pdfs/ADA460 627.pdf (accessed on 17 May 2021).

32. van Rijn, L.C. Unified view of sediment transport by currents and waves. I: Initiation of motion, bed roughness, and bed-load transport. J. Hydraul. Eng. 2007, 133, 649-667. [CrossRef]

33. Courant, R.; Friedrichs, K.; Lewy, H. On the Partial Difference Equations of Mathematical Physics. IBM J. Res. Dev. 1967, 11, 215-234. [CrossRef]

34. Bentley, S.J., Sr.; Blum, M.D.; Maloney, J.; Pond, L.; Paulsell, R. The Mississippi River source-to-sink system: Perspectives on tectonic, climatic, and anthropogenic influences, Miocene to Anthropocene. Earth-Sci. Rev. 2016, 153, 139-174. [CrossRef]

35. Ameen, A.D.; Kolker, A.S.; Taylor, C.M. Vegetation and shear strength in a delta-splay mouth bar. Wetlands 2017, 37, 1159-1168. [CrossRef]

36. Allison, M.A.; Meselhe, E.A. The use of large water and sediment diversions in the Lower Mississippi River (Louisiana) for coastal restoration. J. Hydrol. 2010, 387, 346-360. [CrossRef]

37. White, E.D.; Reed, D.J.; Meselhe, E.A. Modeled sediment availability, deposition, and decadal land change in coastal Louisiana marshes under future sea level rise scenarios. Wetlands 2019, 39, 1233-1248. [CrossRef]

38. Meselhe, E.A.; Roelvink, D.; Wackerman, C.; Xing, F.; Vo, Q.T. Modeling the process response of coastal and deltaic systems to human and global changes. Oceanography 2017, 30, 84-97. [CrossRef]

39. Allison, M.; Weathers, D.; Meselhe, E.A. Bottom morphology in the Song Hau Distributary Channel, Mekong River Delta, Vietnam. Cont. Shelf Res. 2017, 147, 51-61. [CrossRef] 